\title{
PEMANFATAN SENSOR ANDROID SEBAGAI MEDIA EKSPERIMEN PADA MATERI GERAK HARMONIS SEDERHANA
}

\section{Utilization of Android Censor as Experimental Tool in Simple Pendulum}

\author{
Harjono \\ SMAN Cahaya Madani Banten Boarding School (CMBBS) \\ Jl. Labuan Km. 3, Kuranten, Pandeglang, Banten \\ harjono@igi.or.id
}

\footnotetext{
Diterima:

10 September 2019

Direvisi:

10 September 2019

Disetujui:

13 Desember 2021
}

\begin{abstract}
ABSTRAK: Pemanfaatan aplikasi android sebagai media pembelajaran semakin luas dan banyak digunakan oleh guru maupun siswa dalam belajar. Namun, pemanfaatan aplikasi android dan sensor yang tertanam dalam smartphone android belum banyak digunakan dalam dunia pendidikan khususnya bidang sains dan utamanya pelajaran fisika. Tujuan penelitian ini adalah mengembangkan alat percobaan atau eksperimen menggunakan smartphone android dengan memanfaatkan aplikasi dan sensorpada android beserta lembar kerja praktikum (LKP), serta mengetahui seberapa efektif media ini digunakan. Penelitian ini dilaksanakan di SMAN CMBBS dengan mengadopsi pengembangan model ADDIE yang meliputi tahapan Analysis, Design, Development, Implementation, and Evaluation. Tahap Analysis dilakukan dengan menganalisis kebutuhan media dengan fokus pada siswa dan materi. Tahap Design adalah membuat rancangan media, yaitu media percobaan ayunan sederhana menggunaan android. Pada tahap ini, ada tahapan validasi ahli materi. Tahap selanjutnya adalah tahap Development atau Pengembangan, yaitu proses mewujudkan rancangan menjadi sebuah produk. Pada tahap ini juga dilakukan uji coba kelas. Selanjutnya adalah tahap Implementation, yaitu mengimplementasikan media dalam kegiatan pembelajaran. Responden penelitian ini adalah siswa yang akan melakukan uji coba media dan sebagian diantaranya akan mengimplementasi media. Penelitian berhasil mengembangkan alat praktikum ayunan sederhana menggunakan aplikasi phyphox dan mengembangkan LKP untuk mempermudah penggunaan oleh siswa. Alat praktikum dan LKP yang disusun dinyatakan sangat layak untuk digunakan berdasarkan indikator kelayakan media baik dari segi tampilan, efisiensi, desain alat, keberfungsian alat, dan kemenarikan berdasarkan validasi validator dan respon uji siswa. Hasil penggunaan produk menunjukkan hasil yang baik dengan nilai rata-rata siswa di atas kriteria ketuntasan minimal.
\end{abstract}

Kata Kunci: smartphone, android, sensor, phypox, praktikum

ABSTRACT: The utilization of android application as learning media by teachers and students is getting wider. However, the utilization of android application and censor installed in android smartphone for education, especially in Physics, is still little. The objectives of this research are to develop an experimental tool by 
using android smartphone, its application and censor, as well as its experimental worksheet, and to know how effective this media usage is. This research is carried out at SMAN CMBBS with ADDIE research development model: Analysis, Design, Development, Implementation and Evaluation. The Analysis phase is conducted through analyzing the need for media with the focus on the students and the material. The Design phase is by creating media design, i.e. android-based simple pendulum experimental media. The Development phase is to realizing the design into a product. In this phase, there is a classical trial. The next phase is Implementation, i.e. utilizing the media in the learning activities. For Student respondents, they are divided into respondents for media testing and respondents for media implementation. The research succeeds in developing a simple pendulum practicum tool by using the phyphox application and a practicum worksheet for easier usage by the students. The practicum tools and worksheets are stated highly feasible to use based on the media feasibility indicators: features, efficiency, tool design, tool functionality, and attractiveness that have been validated by the validators and students' test responses. The tool utilization shows a good result, indicated by the average score that is higher than the Minimum Completeness Criteria.

Keywords: smartphone, android, censor, phypox, practicum

\section{PENDAHULUAN}

Media pembelajaran dalam bentuk aplikasi android saat ini semakin luas digunakan oleh siswa maupun guru baik di kelas maupun di luar kelas. Aplikasi android yang digunakan lebih banyak berisi konten materi ataupun animasi untuk menjelaskan konsep suatu materi. Penggunaan smartphone android sebagai alat eksperimen masih belum banyak digunakan di sekolah, padahal smartphone andoroid punya potensi untuk dimanfaatkan sebagai alat praktikum dengan sensor yang tertanam di dalamnya. Saat ini, perangkat seluler menggunakan sensor yang tertanam di dalamnya seperti akselerometer, kompas, GPS, kamera, dan mikrofone (Aram et al., 2012). Platform android menyediakan beberapa sensor yang memungkinkan kita memantau gerakan smartphone. Dua sensor selalu berbasis hardware (accelerometer dan giroskop) dan yang ketiga dapat berbasis software seperti accelerometer dan magnetometer. Namun, pada perangkat lain juga dapat menggunakan giroskop untuk mendapatkan datanya. Ketersediaan sensor berbasis software lebih bervariasi karena mereka sering bergantung pada salah satu atau lebih sensor hardware untuk menurunkan datanya (Suciarahmat \& Pramudya, 2015).

Berbagai sensor ini memungkinkan untuk digunakan dalam eksperimen. Perkembangan pada smartphone telah berdampak pada praktik mengajar, karena berbagai eksperimen dapat dilakukan dengan mudah menggunakan sensor yang biasanya tersedia di smartphone. Beberapa karya terbaru yang menggunakan smartphone dalam percobaan laboratorium adalah pada materi mekanika, elektromagnet, optik, osilasi, dan gelombang (Monteiro dkk., 2015).

Penggunakan aplikasi pada smartphone sebagai alat eksperimental bisa mengatasi masalah terbatasnya sarana dan prasarana laboratorium di sekolah dan mahalnya biaya untuk membeli peralatan eksperimen. Penggunaan smartphone sebagai alat percobaan meningkatkan minat siswa dalam 
belajar. Eksperimen juga sangat mudah dilakukan di kelas, karena semua alat dan bahan yang digunakan dalam eksperimen tersedia dan berbiaya rendah (Kapucu, 2017). Jadi, aplikasi pada smartphone akan mempermudah guru dan siswa untuk melakukan percobaan di kelas maupun di luar kelas.

Saat ini banyak sekali laboratorium maya yang dapat mendukung kegiatan eksperimen. Laboratorium maya adalah suatu alat pembelajaran berupa software yang berisi peristiwa atau jalannya percobaan dalam bentuk animasi (Ardius, 2020). Salah satu portal yang menyediakan laboratorim maya adalah Rumah Belajar. Fitur simulasi praktikum laboratorium yang ada disajikan secara interaktif dan menarik, dikemas bersama lembar kerja siswa dan teori praktikum (https://belajar.kemdikbud. go.id:2021) (Kemendikbudristek, n.d.). Pada laboratorim maya praktikum dilakukan melalui simulasi sehingga pengalaman nyata kurang dapat diperoleh oleh peserta didik.

Dari hasil penelitian Kadir (2014 yang membandingkan efektivitas antara laboratorium maya dan laboratorium riil, diperoleh hasil bahwa laboratorium riil lebih efektif dibandingkan dengan laboratorium maya. Kegiatan praktikum di laboratorim tidak selalu menghasilkan data yang benar sesuai teori. Hal ini terjadi karena keterbatasan alat yang tersedia, kesalahan dalam pengukuran, ataupun kesalahan-kesalahan praktikan dalam melakukan percobaan. Kesalahan yang terjadi dalam praktikum ini akan menimbulkan kesulitan dalam membuktikan suatu teori maupun kesulitan menemukan sesuatu yang akan dipelajari. Penggunaan sensor pada smartphone diharapkan dapat memudahkan dan membantu dalam pemahaman pembelajaran Fisika (Nurul $\mathrm{H}$. et al., 2017). Salah satu alternatif lain yang dapat kita gunakan adalah penggunakan sensor percepatan smartphone. Smartphone sangat cocok sebagai alat eksperimental, karena biasanya dilengkapi dengan sejumlah sensor. Sebagai contoh, sebagian besar smartphone memiliki mikrofon, sensor percepatan, sensor kuat medan magnet, sensor cahaya dan penerima GPS. Karena semua sensor dapat dibaca oleh aplikasi yang diperlukan, sejumlah penelitian kuantitatif dapat dilakukan dengan smartphone (Kuhn \& Vogt, 2013)

Phyphox merupakan aplikasi berbasis android dan iphone yang dikembangkan oleh RWTH Aachen University. Phyphox memberikan akses ke sensor ponsel baik secara langsung atau melalui eksperimen yang kemudian menganalisis data yang dihasilkan atau bisa mengekspor data mentah bersama dengan hasil untuk analisis lebih lanjut. Bahkan aplikasi ini dapat menentukan percobaan sendiri di phyphox. org dan berbagi dengan rekan sejawat, siswa dan teman-teman (Phyphox.org, n.d.) (diakses 3 September 2019).

Aplikasi Phyphox menjadikan smatphone sebuah magnetometer $3 D$, dan ponsel dapat digunakan sebagai pendulum untuk mengukur percepatan gravitasi lokal bumi. Ponsel juga dapat diubah menjadi sebuah sonar. Aplikasi ini menjadikan sensor yang ada dalam handphone sebagai alat percobaan Fisika. Berbagai sensor yang didukung aplikasi adalah sensor accelerometer, magnetometer, gyroscope, intensitas cahaya, tekanan, mikrofon, proximity, dan GPS. Beberapa sensor tersebut tidak tersedia pada setiap ponsel. (https://play.google.com/phyphox ) (Store, n.d.).

Penggunaan aplikasi Phypox ataupun aplikasi android sebagai media pembelajaran atau media praktikum sudah banyak dilakukan, di antaranya seperti yang dinyatakan dalam suatu artikel berjudul "Alat Canggih untuk Eksperimen: Phiphox" (S. Staacks etal., 2018), yaitu bahwa eksperimen berbasis smartphone dapat memotivasi siswa karena memungkinkan mereka mengekplorasi Fisika dengan alat mereka sendiri. Penggunaan lain dari phyphox dalam eksperimen adalah untuk percobaan Tumbukan (Nurfadilah et al., 2019). Dari segi keefektifan dalam penggunaan dan keakuratan dalam mengolahan data hasil percobaan, aplikasi phyphox ini danggap efektif dan akurat saat digunakan dalam 
percobaan menghitung konstanta pegas (Dea Julianingsih, S Supryatna, 2019) .

Berdasarkan uraian di atas, penulis tertarik untuk mengembangkan alat percobaan ayunan sederhana menggunakan smartphone android dengan memanfaatkan fitur dan sensor yang tersedia di dalamnya. Adapun perumusan masalah dalam penelitian ini adalah bagaimana mengembangkan smartphone android sebagai alat percobaan beserta lembar kerja paraktikum (LKP).

Berdasarkan uraian masalah tersebut, dapat dirumuskan tujuan penelitain ini, yaitu: 1) mengembangkan alat percobaan ayunan sederhana menggunakan smartphone android dengan memanfaatkan aplikasi dan sensor pada android beserta LKP; 2) mengetahui kelayakan media percobaan berbasis android dan LKP; dan 3) mengetahui keefektifan alat praktikum menggunakan smartphone berbasis android beserta LKP.

\section{METODE}

Penelitian pengembangan ini menggunakan metode ADDIE (Analysis, Design, Development, Implementation and Evaluation). yang dikembangkan oleh-Dick and Carry dalam (Sugiyono, 2017:28). Pada penelitian ini hanya dibatasi pada tahap pengembangan dan uji kelayakan secara terbatas.

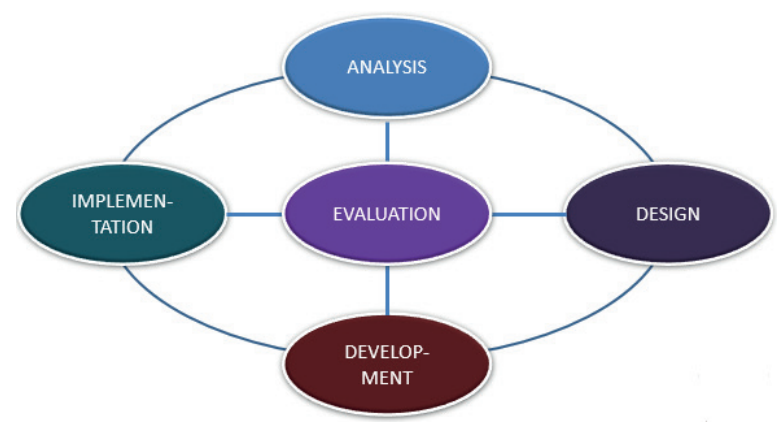

Gambar 1. Desain Pengembangan ADDIE (Sugiyono:2017)

Tahap analisis dilakukan dengan menganalisis kebutuhan akan media. Oleh karena itu kegiatan analisis ini difokuskan pada analisis siswa dan analisis materi. Tahap perancangan atau tahap pembuatan rancangan media. Media yang akan dibuat adalah media percobaan ayunan sederhana menggunaan android. Media ini menggunkan smartphone android sebagai ayunan, dan memanfaatkan sensor dan aplikasi di dalamnya untuk menentukan besaranbesaran yang akan dicari seperti periode, amplitudo, dan lain sebagainya. Tahapan perancangan meliputi: 1) pemilihan hardware dan software yang akan digunakan sebagai alat/media praktikum. Media yang dibuat ini memanfaatkan sensor pada smartphone android yaitu sensor accelerometer dan giroskop. Sensor ini yang akan dipakai dalam menentukan periode, frekuensi, dan percepatan gravitasi; 2) penyusunan LKP; dan 3 ) penyusunan soal tes untuk evaluasi.

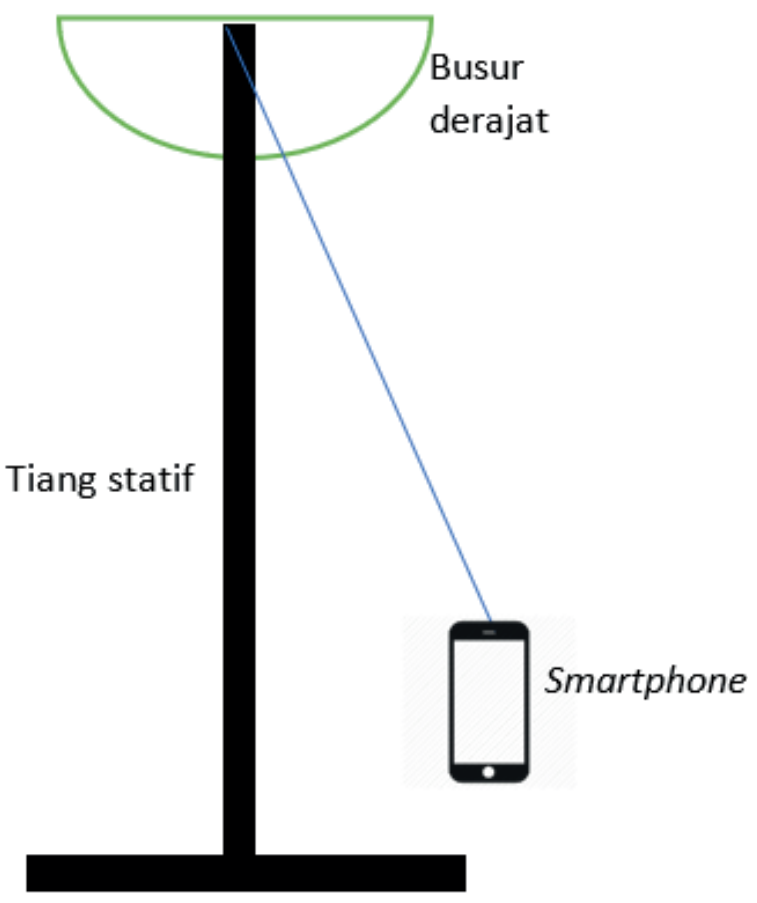

Gambar 2. Rancangan Alat Percobaan Ayunan Sederhana dengan Smartphone

Tahap pengembangan adalah proses mewujudkan rancangan menjadi sebuah produk pengembangan. Pengembangan yang dilakukan adalah merancang media atau alat percobaan ayunan sederhana menggunakan smarphone android dengan memanfaatkan sensor dan aplikasi yang ada di dalamnya dan menyusun lembar kerja atau pedoman percobannya. Setelah produk awal jadi, berikutnya dilakukan pengujian 
awal berupa validasi. Validasi dilakukan oleh praktisi. Hasil validasi digunakan untuk revisi atau penyempurnaan produk dan perangkat. Untuk validator media dan materi oleh ahlinya yaitu dosen pengajar Fisika dan guru Fisika senior yang sudah mengajar lebih dari 20 tahun dan saat ini sebagai ketua MGMP Fisika tingkat kabupaten. Setelah uji validasi ahli, selanjutnya adalah evaluasi satu-satu kepada tiga orang murid, untuk mencoba dan menggunakan lembar kerja untuk dasar perbaikan kembali sebelum uji coba kelas terbatas. Selanjutnya adalah uji coba di kelas terbatas. Hasil uji coba digunakan untuk memperbaiki sistem pembelajaran maupun langkah percobaan yang mengalami masalah. Tahapan evaluasi uji coba kelas yaitu dengan memberikan angket kepada responden terkait alat maupun lembar kerja yang digunakan. Angket validasi hasil responden siswa dianalisis dengan skala likert. Penelitian ini dilakukan di SMAN CMBBS dengan sampel kelas $X$, terdiri atas satu kelas digunakan sebagai responden uji coba produk dan satu kelas sebagai kelas implementasi. Penelitian dilakukan pada bulan Agustus sampai September 2018.

Tahapan berikutnya adalah implementasi pada kelas uji coba yang sebenarnya. Tahap implementasi merupakan tahap uji pengembangan alat praktikum dan LKP. Tahap implementasi dilakukan terbatas pada satu kelas $\mathrm{X}$ semester 2 , yang belajar materi gerak harmonis sederhana topik ayunan atau bandul sederhana.

Tahap berikutnya adalah tahap evaluasi. Pada tahap evaluasi dilakukan pengukuran kevalidan, respons, dan keefektifan dalam pembelajaran dengan menggunakan alat praktikum ayunan android dan LKP. Oleh karena itu, disusun dan dikembangkan instrumen penelitian berupa: 1) lembar angket respona siswa; dan 2) post test.

Angket validasi dianalisis dengan skala Likert yang menggunakan skala 1 sampai 4 dengan pedoman penilaian seperti pada tabel 2. Skala likert digunakan untuk mengukur sikap, pendapat, dan persepsi seseorang mengenai suatu fenomena
(Sugiyono, 2016, hal. 93). Respons siswa dianalisis menggunakan skala Likert seperti pada Tabel 1.

Tabel 1. Skor Respons Siswa

\begin{tabular}{lll}
\hline No & $\begin{array}{l}\text { Skor } \\
\text { pertanyaan } \\
\text { positif }\end{array}$ & Pernyataan \\
\hline 1 & 4 & Sangat Setuju \\
\hline 2 & 3 & Setuju \\
\hline 3 & 2 & Tidak Setuju \\
\hline 4 & 1 & Sangat Tidak Setuju \\
\hline
\end{tabular}

Kategori skor dalam skala Likert dijelaskan pada Tabel 2.

Tabel 2. Kategori Skor (Sugiyono, 2016:93)

\begin{tabular}{|c|c|}
\hline \multirow{3}{*}{$\begin{array}{l}\text { skala } \\
1\end{array}$} & Kriteria terhadap produk \\
\hline & Kurang setuju/kurang baik/kurang \\
\hline & $\begin{array}{lr}\text { sesuai/kurang } & \text { mudah/kurang } \\
\text { paham/kurang } & \text { menarik/kurang } \\
\text { mengerti/kurang } & \text { layak/kurang } \\
\text { bermanfaat/kurang } & \text { memotivasi// } \\
\text { kurang aktif } & \end{array}$ \\
\hline \multirow[t]{5}{*}{2} & Cukup setuju/cukup \\
\hline & sesuai/cukup \\
\hline & paham/cukup \\
\hline & $\begin{array}{ll}\text { mengerti/cukup } & \text { layak/cukup } \\
\text { bermanfaat/cukup } & \text { memotivasi/ }\end{array}$ \\
\hline & cukup aktif \\
\hline 3 & $\begin{array}{l}\text { Setuju/baik/sesuai/mudah/paham } \\
\text { /menarik/mengerti/layak/bermanf } \\
\text { aat/ memotivasi/ aktif }\end{array}$ \\
\hline 4 & Sangat setuju/sangat baik/sangat \\
\hline & sesuai/sangat mu \\
\hline & $\begin{array}{ll}\text { paham/sangat } & \text { men } \\
\text { mengerti/sangat }\end{array}$ \\
\hline & $\begin{array}{l}\text { bermanfaat/sangat } \\
\text { sangat aktif. }\end{array}$ \\
\hline
\end{tabular}

Kemudian kuesioner hasil respons siswa dianalisis dan dipersentasekan menggunakan rumus berikut:

\section{Keterangan:}

$P=$ jumlah persentase yang dicapai pada setiap alternatif jawaban

$f=$ frekuensi siswa yang memilih suatu alternatif jawaban 
Tanggapan atau pendapat siswa dapat dilihat dari hasil persentase setiap pertanyaan. Pedoman interpretasi data yang digunakan sebagaimana Tabel 3.

Tabel 3. Kriteria Respons Siswa (Arikunto, 2013, hal. 281)

\begin{tabular}{llll}
\hline No & $\begin{array}{l}\text { Tingkat } \\
\text { Pencapaian }\end{array}$ & Kualifikasi & Keterangan \\
\hline 1 & $81 \leq x \leq 100 \%$ & Sangat baik & $\begin{array}{l}\text { Sangat baik, } \\
\text { tidak perlu } \\
\text { revisi }\end{array}$ \\
\hline 2 & $61 \leq x \leq 80 \%$ & baik & $\begin{array}{l}\text { Layak, tidak } \\
\text { perlu revisi }\end{array}$ \\
\hline 3 & $41 \leq x \leq 60 \%$ & Cukup baik & $\begin{array}{l}\text { Kurang layak, } \\
\text { perlu revisi }\end{array}$ \\
\hline 4 & $21 \leq x \leq 40 \%$ & Kurang baik & $\begin{array}{l}\text { Tidak layak, } \\
\text { perlu revisi }\end{array}$ \\
\hline
\end{tabular}

Tahap evaluasi merupakan tahap yang terakhir digunakan untuk mengukur keberhasilan penggunaan alat praktikum ayunan android dan LKP. Dalam penelitian ini, tahap evaluasi akhir dilakukan dengan mengevaluasi data-data hasil ketuntasan dari nilai post-test. Keberhasilan dari penggunaan alat dan LKP ini dilihat dari hasil ketuntasan belajar siswa. Pencapaian ketuntasan belajar siswa secara klasikal dapat dilihat dari persentase siswa yang tuntas belajarnya.

\section{HASIL DAN PEMBAHASAN}

Pengembangan alat pembelajaran berupa alat praktikum materi ayunan gerak harmonis sederhana ini menggunakan smartphone berbasis aplikasi android phyphox dan pengembangan LKP menggunakan model $A D D I E$ yang terdiri dari tahapanalisis (analysis), perancangan desain (design), pengembangan (development), implementasi (implementation), dan evaluasi (evaluation). Berdasarkan tahapan penelitian yang telah dilakukan, berikut ini disajikan hasil penelitiannya.

\section{Tahap Analisis}

Tahap analisis ini merupakan tahapan awal dari penelitian pengembangan alat praktikum ayunan sederhana menggunakan smartphone berbasis aplikasi android phypox dan LKP. Pada tahap ini, analisis yang dilakukan adalah analisis kebutuhan media sumber belajar, analisis karakteristik peserta didik, dan analisis kurikulum. Berdasarkan hasil observasi, diperoleh hasil analisis sebagai berikut: a) analisis kebutuhan terkait media sumber belajar. Sumber belajar di SMAN CMBBS Pandeglang Banten secara umum bisa dikatakan cukup memadai. Sarana laboratorium Fisika juga bisa dikatakan cukup lengkap untuk praktikum materi mekanika khususnya seperti gerak, gaya, getaran, dan lain-lain. Akan tetapi di sisi lain, kemajuan dan perkembangan teknologi memberikan harapan baru dalam media pendidikan, yaitu penggunaan sensor pada smartphone untuk digunakan dalam praktikum. Jadi di sini ada, potensi dari smartphone untuk dijadikan sebagai alat bantu praktikum. Oleh karena itu, peneliti tertarik untuk mengembangkan alat praktikum menggunakan sensor dan aplikasi pada smartphone; b) analisis karakteristik peserta didik. Dari hasil pengamatan, peserta didik kelas $\mathrm{X}$ maupun kelas $\mathrm{XI}$ di SMAN CMBBS kebanyakan berusia 1617 tahun, di mana pada usia tersebut siswa banyak memiliki rasa penasaran dan keingintahuan terhadap ilmu pengetahuan. Rasa keingintahuan mereka terhadap tekhnologi dan kedekatan mereka terhadap smartphone yang sudah biasa mereka gunakan menjadikan penulis semakin bersemangat untuk mengembangkan alat praktikum menggunakan smartphone dengan aplikasi android yang terpasang di dalamnya; dan c) analisis kurikulum. Kurikulum yang digunakan di SMAN CMBBS adalah Kurikulum 2013 yang sudah direvisi. Pada kurikulum ini terdapat 4 kompetensi inti yang dicapai peserta didik setelah melaksanakan proses pembelajaran yaitu spiritual, sikap sosial, pengetahuan, dan keterampilan. Materi semester genap yang digunakan pada penelitian ini adalah materi gerak harmonis sederhana.

Sebagai acuan pembelajaran yang dilakukan adalah Kompetensi Inti (KI) dan Kompetensi Dasar (KD) seperti yang termuat dalam Permendikbud Nomor 24 Tahun 2016 
tentang Kompetensi Inti dan Kompetensi Dasar pelajaran kurikulum 2013. Kompetensi dasar yang akan dicapai pada materi gerak harmonis sederhana adalah seperti yang ditampilkan dalam Tabel 4.

Tabel 4. Kompetensi Dasar Materi Gerak Harmonis Sederhana

\begin{tabular}{llr}
\hline 3.11 Menganalisis & 4.11 & Melakukan \\
hubungan antara & percobaan & getaran \\
gaya dan getaran & harmonis & pada \\
dalam kehidupan & ayunan sederhana \\
sehari-hari & dan/atau & getaran \\
& pegas & berikut \\
& presentasi r hasil \\
& percobaan serta & \\
& & makna fisisnya
\end{tabular}

\section{Tahap Desain}

Tahap berikutnya atau tahap kedua dalam penelitian ini adalah tahap desain atau tahap perancangan. Tahap perancangan pada penelitian ini dibagai menjadi 4 tahap yaitu perancangan alat praktikum, perancangan LKP, perancangan alat praktikum, dan perancangan strategi pembelajarannya.

Tahap pertama yaitu pembuatan alat praktikum dan penentuan hardware serta software yang akan digunakan. Media yang dibuat ini memanfaatkan sensor pada smartphone android yaitu sensor accelerometer dan giroskop. Sensor ini yang akan dipakai dalam menentukan periode, frekuensi, dan nilai percepatan gravitasi di tempat tersebut. Dimulai dari penentuan hardware sesuai dengan kebutuhan sensor yang akan digunakan, dipilihlah smartphone yang mempunyai sensor accelerometer dan giroskop. Selanjutnya menentukan software atau aplikasi android yang akan digunakan. Ada beberapa pilihan yang akan digunakan, di antaranya adalah vibration analysis, accel data capture, dan phyphox. Setelah melakukan pengujian terhadap ketiga aplikasi, akhirnya pilihan dijatuhkan pada penggunaan aplikasi phyphox. Pemilihan ini dilakukan dengan pertimbangan kemudahan penggunaan, tampilan, dan tampilan data yang mudah dibaca. Phyphox merupakan aplikasi android yang memanfaatkan sensor yang tertanam dalam smartphone (HP) sebagai alat eksperimen.

Setelah menentukan hardware dan software yang digunakan, selanjutnya membuat rancangan alat yang akan dibuat. Sesuai rencana, alat yang akan dibuat adalah alat percobaan ayunan sederhana menggunakan aplikasi android. Desain alat tidak jauh berbeda dengan alat percobaan ayunan sederhana. Hanya di sini bandul yang digunakan adalah smartphone yang sudah diinstal phyphox. Desain alat bisa dilihat pada Gambar 3.

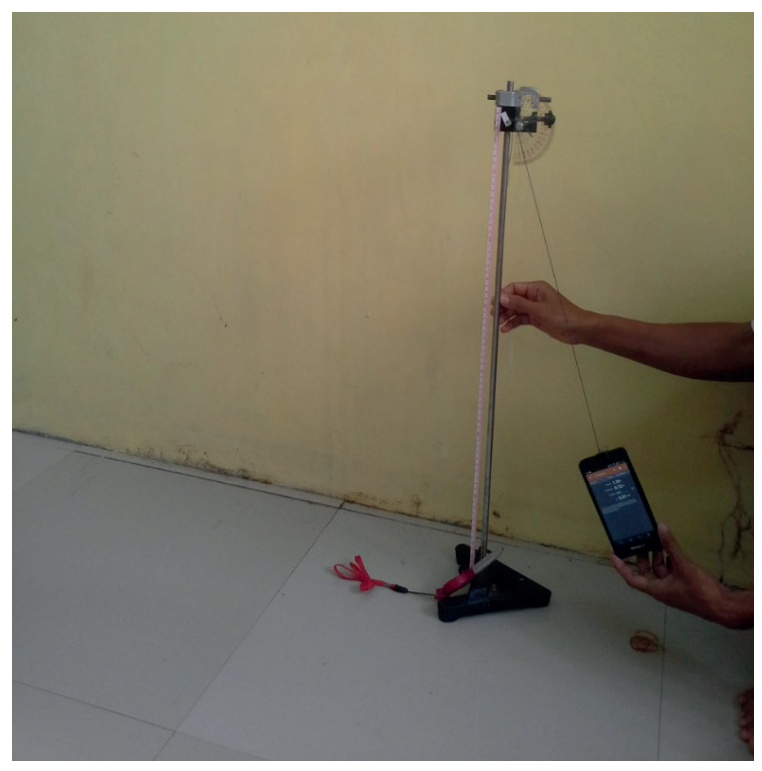

Gambar 3. Rancangan Alat Percobaan Ayunan Sederhana Menggunakan Smartphone

Cara kerja atau penggunaan alat ini dijelaskan berikut ini. Pertama, kita install aplikasi phyphox dari playstore. Setelah aplikasi terpasang, rakit peralatan seperti Gambar 3. Kita beri simpangan sudut kecil dengan acuan busur derajat seperti halnya ketika kita melakukan percobaan ayunan sederhana menggunakan bandul atau beban. Sebelum HP dilepaskan sehingga berayun, buka aplikasi phyphox kemudian pilih pendulum atur waktu delay dan waktu pengukuran. Setelah itu klik tombol play, kemudian HP dilepaskan sehingga berayun. Beberapa saat setelah waktu delay habis, aplikasi di HP akan menghitung periode, 
frekuensi, dan percepatan gravitasi secara otomatis menggunakan sensor yang terpasang di dalamnya. Daftar alat dan petunjuk penggunaan ini ditulis di LKP yang disusun.

Tahap kedua dalam perancangan adalah penyusunan LKP. LKP merupakan pedoman langkah kerja percobaan yang sangat diperlukan agar kegiatan percobaan/ eksperimen dapat berjalan sesuai rencana dan tujuannya dapat tercapai. LKP disusun dengan urutan sebagai berikut: Judul Percobaan, Keterangan Percobaan Secara Singkat, Teori, Tujuan Percobaan, Alat dan Bahan, Prosedur Percobaan, Data Percobaan, Analisis Data, dan Kesimpulan.

Tahap ketiga dalam perancangan adalah penyusunan Instrumen Tes. Instrumen yang disusun dalam penelitian ini meliputi instrumen pengukur kelayakan produk dan instrumen tes untuk melihat hasil atau efektivitas dari penggunaan produk. Ada beberapa instrumen yang digunakan untuk mengukur kelayakan produk yang dikembangkan oleh peneliti. Instrumen tersebut meliputi instrumen untuk validasi ahli media praktikum Fisika dan instrumen validasi ahli materi untuk alat praktikum dan LKP, instrumen validasi pengguna uji coba produk, dan instrumen respons siswa penggunaan produk. Instrumen terakhir adalah instrumen untuk melihat hasil atau efektivitas dari penggunaan produk. Instrumen tes yang disusun pada penelitian digunakan untuk post-test yang diberikan kepada siswa setelah pembelajaran menggunakan media pembelajaran yang diterapkan di kelas/laboratorium. Jenis tesnya adalah tes uraian. Data hasil tes akan digunakan untuk melihat keefektifan produk yang dibuat.

Tahap keempat dalam perancangan yaitu merancang strategi pembelajaran. Pembelajaran yang digunakan adalah model eksperimen. Siswa akan melakukan percobaan/ eksperiman dengan menggunakan alat ayunan sederhana berbasis aplikasi android menggunakan smartphone.

\section{Tahap Pengembangan}

Tahap pengembangan meliputi pengembangan pembuatan alat praktikum berbasis aplikasi android dan LKP serta validasi produk tersebut. Setelah alat praktikum dan LPK dibuat kemudian dilakuan validasi. Validasi dilakukan oleh dua orang yaitu seorang dosen Fisika dan seorang guru senior ketua MGMP Fisika yang telah mempunyai pengalaman mengajar lebih dari 20 tahun. Setelah dilakukan validasi ahli berikutnya produk diuji cobakan di kelas dan dilakukan validasi pengguna uji coba.

Produk yang telah dikembangkan berupa alat praktikum ayunan sederhana pada gerak harmonis menggunakan smartphone berbasis aplikasi android dan (LKP diajukan ke validator untuk dilakukan validasi. Validasi oleh validator ini dilakukan sebelum pelaksanaan uji coba. Proses validasi dilakukan oleh ahli alat praktikum dan ahli materi.

Hasil validasi dari validator menunjukkan skor rata rata dalam persentase sebesar $95,75 \%$ untuk alat praktikum, yang artinya masuk kategori sangat baik atau sangat layak, sedangkan hasil untuk LKP memperoleh skor rata-rata sebesar $96,4 \%$ yang berarti dalam kategori sangat baik. Hasil validasi tersebut menunjukan bahwa alat praktikum yang dikembangkan beserta LKP layak untuk dilanjutkan pada tahap berikutnya yaitu tahap ujicoba produk. Penentuan tingkat kelayakan media dari validasi ahli didasarkan pada interval persentase penilaian produk berdasarkan panduan. Selain memberikan nilai validasi, validator juga memberikan saran perbaikan sebagaimana ditampilkan dalam Tabel 5. 
Tabel 5. Saran Perbaikan dari Validator

\begin{tabular}{ll}
\hline No & sebelum perbaikan \\
\hline 1 & Pada kaki statis yang digunakan \\
pada alat praktikum memungkinkan \\
terjadinya goncangan ketika \\
digunakan sehingga bisa saja jatuh \\
dan HP mengalami kerusakan. \\
Lihat gambar dibawah \\
Gambar sebelum perbaikan \\
Saran perbaikan \\
Kaki Statis diberikan klem yang \\
dipasang di kaki statif dengan meja \\
sehingga statif akan kokoh tidak \\
bergoyang ketika digunakan, \\
sehingga akan lebih aman untuk \\
digunakan. \\
Gambar setelah perbaikan \\
S a
\end{tabular}

Saran perbaikan untuk LKP adalah sebagaimana ditunjukkan dalam Tabel 6.

Tabel 6. Saran Perbaikan LKP dari Validator Validator

\begin{tabular}{|c|c|}
\hline $\begin{array}{l}\text { Sebelum } \\
\text { Perbaikan }\end{array}$ & Saran Perbaikan \\
\hline $\begin{array}{l}\text { Pada LKP kerja } \\
\text { tidak ada } \\
\text { pernyataan } \\
\text { untuk menjaga } \\
\text { keamanan }\end{array}$ & $\begin{array}{l}\text { Pada bagian LKP perlu } \\
\text { ditambahkan cara } \\
\text { mengikat smartphone } \\
\text { pada kaki statis dengan } \\
\text { menambahkan klem }\end{array}$ \\
\hline $\begin{array}{l}\text { smartphone } \\
\text { agar tidak } \\
\text { mudah jatuh. }\end{array}$ & $\begin{array}{l}\text { agar tidak mudah jatuh } \\
\text { atau lepas dari ikatan }\end{array}$ \\
\hline
\end{tabular}

Setelah dilakukan perbaikan pada produk berdasarkan masukan dari validator, selanjutnya dilakukan evaluasi satu-satu oleh tiga orang murid. Menurut murid, harus ada informasi atau petunjuk bagaimana setting aplikasi agar data yang dihasilkan akurat, kemudian font pada LKP agar lebih dibesarkan agar lebih jelas dan bahasa agar lebih disederhanakan. Selanjutnya produk di ujicobakan di kelas. Ujicoba pertama disebut sebagai ujicoba produk dilakukan pada kelompok atau responden terbatas. Setelah murid melakukan ujicoba, kemudian diberikan angket dan dari hasil angket kelompok responden, diperoleh hasil rata-rata skor 81,64 untuk alat praktikum, yang berarti berada dalam rentang kategori sangat baik menurut Arikunto, sedangkan untuk LKP diperoleh hasil 75,22 yang berada dalam rentang kategori baik. Hasil ujicoba produk tersebut menunjukan bahwa alat praktikum yang dibuat memiliki tingkat kelayakan yang sangat baik dan layak untuk dilanjutkan pada tahap berikutnya. Dengan demikian, alat praktikum beserta LKP sangat layak untuk digunakan dalam proses pembelajaran, dalam hal ini untuk kegiatan praktikum.

\section{Tahap Implementasi}

Tahap berikutnya adalah tahap implementasi yaitu implementasi produk di lapangan. Implementasi produk dilakukan pada kelas XIPA1 SMAN CMBBS berjumlah 16 orang. Alat praktikum yang sudah dikembangkan beserta LKP. Tahapan pembelajaran yang dilakukan menggunakan pendekatan eksperimen untuk melakukan percobaan ayunan pada gerak harmonis sederhana.

Secara umum, proses pembelajaran diawali dengan pendahuluan, yaitu memberikan informasi mengenai materi yang akan dipelajari, kemudian membagikan LKP. Siswa diberi kesempatan untuk mempelajari LKP, mengikuti langkahlangkah percobannya, dan siswa melakukan percobaan. Setelah siswa melakukan 
percobaan, kemudian siswa diberikan angket respons siswa dan post-test.

Hasil respons siswa terhadap kegiatan pembelajaran dan penggunaan alat praktikum menunjukkan hasil 76,3 yang berarti berada dalam kategori sangat baik. Nilai hasil belajar rata-rata pada ranah kognitif diperoleh sebesar 85,4 yang berarti dalam kategori sangat baik. Hal ini sebagaimana ditunjukkan dalam Tabel 7.

Tabel 7. Hasil Post-test Nilai Kognitif

\begin{tabular}{lr}
\hline Keterangan & Hasil \\
\hline nilai maksimum & 100,0 \\
nilai minimum & 66,7 \\
rata-rata & 85,4 \\
KKM & 76 \\
siswa yang tuntas & 14,0 \\
siswa tidak tuntas & 2 \\
\hline
\end{tabular}

Tabel 7 menunjukkan data hasil posttest nilai kognitif siswa. Nilai post-test menunjukan perolehan nilai maksimum 100 , dan nilai minimum 66,7, dan nilai rerata 85,4. Jika kita mengacu pada jumlah siswa yang mencapai atau melampaui nilai KKM berarti terdapat $87,5 \%$ dari jumlah siswa.

\section{Tahap Evaluasi}

Tahap terahir dari penelitian ini adalah tahap evaluasi. Evaluasi meliputi evaluasi produk berupa alat praktikum dan LKP. Selain itu, juga evaluasi hasil post-test setelah penggunaan alat praktikum ini. Evaluasi hasil validasi ahli oleh validator diperoleh kesimpulan bahwa alat sangat layak untuk digunakan. LKP juga sangat layak digunakan. Untuk hasil ujicoba awal, diperoleh hasil respons siswa yang menyatakan bahwa alat sangat layak digunakan dan LKP layak digunakan. Jika kita perhatikan, hasil dari respons siswa terhadap LKP baru sebatas layak, artinya perlu ada sedikit perbaikan sesuai dengan masukkan siswa. Perbaikan berdasarkan masukan siswa di antaranya adalah untuk penyederhanaan bahasa dalam prosedur percobaan. Kriteria kelayakan alat yang digunakan pada penelitian ini adalah kemudahan dalam penggunaan, keakuratan data yang dihasilkan, kepraktisan dalam penggunaan.

Hasil belajarmenggunakanalatpraktikum berbasis android ini menunjukkan nilai 85,4 yang termasuk dalam kategori sangat baik. Dari hasil angket respons siswa, 76,6\% siswa merasa senang menggunakan ayunan android ini dan $77 \%$ menyatakan praktikum dengan menggunakan ayunan android ini mudah digunakan. Dengan demikian, bisa dikatakan bahwa alat ini memberikan dampak positif bagi siswa. Siswa merasa senang dan mudah dalam belajar menggunakan alat percobaan ayunan android sehingga siswa memperoleh perubahan yang baru dalam dirinya sebagai suatu proses hasil belajar. Seperti yang diungkapkan oleh (Sutikno, 2013:3) memberikan pengertian dari belajar yaitu suatu proses usaha yang dilakukan seseorang untuk memperoleh suatu perubahan yang baru sebagai hasil pengalamannya sendiri dalam interaksi dengan lingkungannya.

Bila ditinjau secara garis besar, alat praktikum yang dikembangkan memiliki beberapa kelebihan dan kekurangan. Kelebihan dari alat praktikum yang dikembangkan yaitu: a) alat praktikum menggunakan smartphone, di mana smartphone merupakan peralatan yang sangat dekat dengan siswa seusia SMA, sehingga siswa lebih familiar dalam penggunaannya. Selain itu siswa juga seperti diajak bermain menggunakan smartphone dalam kegiatan praktikum; b) alat praktikum menggunakan sensor di smartphone sehingga mengurangi tingkat kesalahan dalam pengukuran, karena sensor akan bekerja secara otomatis dan menghasilkan data yang benar asalkan alat atau aplikasi sudah di setting dengan benar; dan c) alat praktikum menggunakan aplikasi android sehingga data akan terbaca secara otomatis, sehingga memudahkan pembacaan data hasil percobaan.

Sedangkan kekurangan dari alat praktikum ini adalah: a) harga smartphone cukup mahal untuk sebagain masyarakat 
kita. Namun dengan asumsi bahwa 40\% siswa telah mempunyai smartphone, sudah bisa untuk digunakan dalam kegiatan praktikum di kelas, yaitu digunakan secara bersama-sama dalam suatu kelompok; dan b) jika tidak hati-hati dalam percobaan, smartphone bisa jatuh dan mengalami kerusakan. Oleh karena itu, perlu kehatihatian dalam penggunaan.

\section{SIMPULAN DAN SARAN}

\section{Simpulan}

Telah berhasil dikembangkan sebuah media pembelajaran berupa alat praktikum ayunan sederhana pada materi gerak harmonis sederhana berbasis aplikasi android menggunakan smartphone yang mempunyai sensor accelerometer dan giroscop dengan memanfaatkan aplikasi android bernama phyphox. Alat praktikum ini dilengkapi dengan LKP yang telah dikembangkan. Media pembelajaran ini dikembangkan dengan metode penelitian pengembangan mengadopsi model ADDIE.

Alat praktikum berbasis aplikasi android dan LKP yang dikembangkan dinyatakan sangat layak untuk digunakan berdasarkan indikator kelayakan media baik dari segi tampilan, efisiensi, desain alat, keberfungsian alat, dan kemenarikan dengan perolehan skor rata-rata sebagai berikut: a) untuk alat praktikum diperoleh nilai hasil validasi validator $95,75 \%$; untuk respons siswa uji coba, diperoleh nilai 81,64. Dengan demikian, alat praktikum dinyatakan sangat layak untuk digunakan; dan b) untuk LKP nilai hasil validasi validator adalah 96,4 $\%$, dan untuk respons siswa hasil ujicoba, diperoleh nilai 75,22. Dengan demikian, LKP juga dinyatakan sangat layak untuk digunakan.

Hasil penggunaan produk menunjukkan respons siswa pengguna dengan skor ratarata 76,3 dan hasil nilai rata-rata post-test siswa sebesar 85,4 . Ini bisa dikategorikan ke dalam kategori baik dengan acuan nilai KKM yaitu 76. Siswa yang mencapai nilai di atas KKM adalah $87,5 \%$.

\section{SARAN}

Berdasarkan hasil penelitian dan pembahasan dapat diajukan saran berikut ini yaitu para guru dapat memanfaatkan sensor pada smartphone android sebagai alat praktikum. Masih banyak materi praktikum yang dapat dilakukan dengan memanfaatkan smartphone android seperti materi gerak, gelombang, magnet, listrik, dan lain sebagainya.

\section{DAFTAR PUSTAKA}

Aram, S., Troiano, A., \& Pasero, E. (2012). Environment sensing using smartphone. 2012 IEEE Sensors Applications Symposium, SAS 2012 - Proceedings, 110-113. https://doi.org/10.1109/ SAS.2012.6166275

Ardius, A. (2020). PEMANFAATAN LABORATORIUM MAYA: PELUANG DAN TANTANGAN The Utilization of Virtual Laboratory: Opportunities and Challenges. Jurnalteknodik, November 2019, 147-160.

Arikunto, S. (2013). Prosedur Penelitian: Suatu Pendekatan Praktik. Rineka Cipta.

Dea Julianingsih, S Supryatna, N. A. (2019). Kefektivitasan Aplikasi phyphox dan Pratikum Sederhana Pegas Sebagai Media percobaan Dalam Menentukan Nilai Konstanta Pegas pada Teknologi Pembejaran Fisika. physEductech, juli, 1.

Kadir, A. R., \& Keguruan, F. T. (2014). Laboratorium Riil Dengan Laboratorium Virtual.

Kapucu, S. (2017). Finding the acceleration and speed of a light-emitting object on an inclined plane with a smartphone light sensor. Physics Education, 52(5). https:// doi.org/10.1088/1361-6552/aa7914

Kemendikbudristek. (n.d.). Portal Rumah Belajar. Kemendikbudristek. https:// belajar.kemdikbud.go.id/

Kuhn, J., \& Vogt, P. (2013). Applications and Examples of Experiments with Mobile Phones and Smartphones in Physics Lessons. Frontiers in Sensors, 1(4). 
Monteiro, M., Cabeza, C., \& Marti, A. C. (2015). Acceleration measurements using smartphone sensors: Dealing with the equivalence principle. Revista Brasileira de Ensino de Fisica, 37(1), 1-6. https://doi.org/10.1590/S180611173711639

Nurfadilah, N., Ishafit, I., Herawati, R., \& Nurulia, E. (2019). Pengembangan Panduan Eksperimen Fisika Menggunakan Smarthphone dengan Aplikasi Phyphox Pada Materi Tumbukan. Jurnal Penelitian Pembelajaran Fisika, 10(2), 101-107. https://doi.org/10.26877/jp2f.v10i2.4019

Nurul H., L. P., Rahmawati, D., Suhendra, D., \& Iskandar, F. (2017). Penggunaan Sensor Magnet pada Smartphone untuk Mengamati Pergerakan Bandul Ganda dalam Eksperimen Fisika. Prosiding SNIPS 2017, 387-391. http://portal. fmipa.itb.ac.id/snips2017/kfz/files/ snips_2017_lale_putri_nurul_hidayah_ xyamrpojgx.pdf

Phyphox.org. (n.d.). phyphox.org. Diambil 3 September 2019, dari www.phypox.org

Staacks, S., Hütz, S., Heinke, H., \& Stampfer, C. (2018). Advanced tools for smartphone- based experiments: phyphox. Physics Education.

Store, P. (n.d.). phyphox. https://play.google. $\mathrm{com} /$ store/apps/details?id=de.rwth_ aachen.phyphox\&hl=in

Suciarahmat, A., \& Pramudya, Y. (2015). Aplikasi Sensor Smartphone dalam Eksperimen Penentuan Percepatan Gravitasi Aplikasi Sensor Smartphone dalam Eksperimen Penentuan Percepatan Gravitasi. Jurnal Fisika Indonesia, XIX(55), 10-13. https://doi. org/https://doi.org/10.22146/jfi.24365

Sugiyono. (2016). Metode Penelitian Kuantitatif, Kualitatif dan R\&D. Alfabeta.

Sugiyono. (2017). Metode Penelitian dan Pengembangan. Alfabeta.

Sutikno, M. S. (2013). Belajar dan Pembelajaran, Upaya Kreatif dalam Mewujudkan Belajar dan Pembelajaran. Holistica. 